BÁN KATALIN

\title{
Az insania jelensége és terápiája Seneca prózai munkáiban
}

\begin{abstract}
A tanulmányban Seneca insaniával kapcsolatos nézeteit vizsgálom meg, annak különböző okai, megnyilvánulási formái és kezelési módjai szempontjából, hiszen sztoikus filozófusként mély érdeklödést mutat az emberek különféle lelki állapotai iránt. Az insania publicát a világban uralkodó általános jelenségnek gondolja, és többnyire a szenvedélyekben, föként a haragban és az abból fakadó bosszúban való elmerülésben jeleníti meg. Leírásában a bölcset a személyes felelösség, az önuralom, a szenvedélyektől való mentesség jellemzi, és az insania akkor jelentkezik, amikor az érzelmek felülkerekednek a racionális gondolkodáson. A szenvedélyeken, a lélekben dúló irracionális erôkön a racionalitásnak kell gyözedelmeskednie, s prózai müveiben a lélek szenvedélyek okozta betegségére ajánl terápiát, életvezetési stratégiát. ${ }^{1}$
\end{abstract}

Kulcsszavak: Seneca, insania, terápia, szenvedély, sztoikus filozófia

A sztoikus filozófia általánosságban a szenvedélyek romboló erejében látja a lelki betegség, „örület” okait, szenvedélymentességet hirdet, amelynek révén az ember teljes nyugalmat nyerhet, és elérheti a lelki egészséget. ${ }^{2}$ Seneca az insaniát hasonlóképp többnyire a szenvedélyekben, főként a haragban, az abból fakadó bosszúban és a túlzott félelemben való elmerülésben jeleníti meg. Szerinte a bölcset a személyes felelösség, az önuralom, a szenvedélyektől való mentesség jellemzi, és az insania akkor jelentkezik, amikor az érzelmek felülkerekednek a racionális gondolkodáson. ${ }^{3}$ A szenvedélyeken, a lélekben dúló irracionális erőkön a racionali-

\footnotetext{
${ }^{1}$ A publikáció az MTA-SZTE Antikvitás és Reneszánsz: Források és Recepció Kutatócsoport (TK2016-126) támogatásával jelent meg.

2 STEIGER (1983).

${ }^{3}$ Ld. bővebben GILL (2013: 372).
} 
tásnak kell győzedelmeskednie, s prózai műveiben a lélek szenvedélyek okozta betegségére ajánl terápiát. A tanulmányban Seneca insaniával kapcsolatos nézeteit vizsgálom meg, hogy milyen okok vezethetnek a kialakulásához, milyen megnyilvánulási formái vannak, illetve milyen kezelési stratégiát ajánl ezekre az abnormális lelki mechanizmusokra.

Seneca sztoikus filozófusként nagy mértéken reflektál elődéire müveiben. A sztoikusok a manifesztálódó szenvedélyeket az egész emberiség „általános” őrületének, a mindennapi életben való megnyilvánulásként tartották. A filozófiai terápia végső célja az apatheia, a teljes és állandó szabadság a szenvedélyektől, a lelki nyugalom, bár ez gyakorlatilag nem volt megvalósítható. Bár a szenvedélyek fölötti uralom fontossága az egész görög etikai gondolkodásnak az alapja, a sztoikus etikában még inkább hangsúlyt kapott. Általánosságban úgy vélték, hogy a szenvedélyek egyfajta ösztönös, nem feltétlen veleszületett, de egyfajta természetes impulzusok (hormé), így a szenvedély vezérelt cselekvés célja önmagában elfogadható. ${ }^{5}$ Ugyanakkor az érzelmeik által irányított emberek gyakran túlzottan, irracionálisan és rossz hiedelmekre alapozva cselekszenek, szenvedést és kárt okoznak. A szenvedélyek többnyire az önközpontú érdekek kielégítésével foglalkoznak, és túlzott megnyilvánulásuk a racionalitást nélkülözi. Így a sztoikus gondolkodásban a szenvedély a lélek betegsége, és őrületként mutatkozik meg.

Seneca már a De ira legelején a haragot rövid őrületnek nevezi (brevis insania), ${ }^{6}$ szerinte az ember a harag állapotában képtelen az önuralomra, és legbensőségesebb kapcsolatainak szálait tépi szét. Voltaképpen az ira és az insania terminusok szinonimaként értelmezhetők, hiszen prózai müveiben többször kifejti: a harag örültség. ${ }^{7}$ Seneca szerint a ratio fennhatósága alatt a szenvedélyek megnyilvánulása még csak el sem tud kezdődni, viszont ha az ész "ellenére" lobbannak fel, rögzülnek. ${ }^{8}$ Hangsúlyozza, hogy a léleknek tudnia kell, hogy hová megy, és honnan jött, mi a jó, és mi a rossz, hogy mit keres, és mit kerül az életben, mi az

\footnotetext{
${ }^{4}$ LONG (2015: 776).

${ }^{5}$ LONG (2015: 775).

${ }^{6}$ Sen. Ir. 1, 1, 2. Vö. Hor. Ep. 1. 2. 62: ira furor brevis est.

7 Pl. Sen. Ir. 3, 34, 2: inde, inquam, uobis ira et insania est, quod exigua magno aestimatis.

8 Sen. Ep. 85, 9.
} 
igazi ratio, hogy meg tudja különböztetni a kívánatost a nemkívánatostól, és ily módon meg tudja szelídíteni vágyainak őrültségét és félelmeit (insania)..$^{9}$ A lényeg az önkontrollon van, azaz hogy időben felismerjük e pusztító jelenségeket, és időben tegyünk ellenük. A filozófus leírásában szenvedélyeknek a lélek hirtelen megnyilatkozó s heves indulatai számítanak, amelyek betegséghez vezethetnek, ha rendszeresek és elhanyagolják őket. ${ }^{10}$ Azaz a szenvedélyek megnyilvánulásának és túltengésének felismerése és öntudatos visszaszorítása, azaz az önkontroll és az akaraterő fontossága megkérdőjelezhetetlen.

Szerzőnk sok helyen az érzelmeket motus animi vagy ictus animi terminusokkal jelöli, amely a lélek az érzelmek irányába való elmozdulását tükrözi:

Et ut scias quemadmodum incipiant adfectus aut crescant aut efferantur, est primus motus non uoluntarius, quasi praeparatio adfectus et quaedam comminatio; alter cum uoluntate non contumaci, tamquam oporteat me uindicari cum laesus sim, aut oporteat hunc poenas dare cum scelus fecerit; tertius motus est iam inpotens, qui non si oportet ulcisci uult sed utique, qui rationem euicit. ${ }^{11}$

\footnotetext{
${ }_{9}$ Sen. Ep. 82, 6: sciat, quo iturus sit, unde ortus, quod illi bonum, quod malum sit, quid petat, quid evitet, quae sit illa ratio, quae adpetenda ac fugienda discernat, qua cupiditatum mansuescit insania, timorum saevitia conpescitur.

10 Sen. Ep. 75, 12: Adfectus sunt motus animi inprobabiles, subiti et concitati, qui frequentes neglectique fecere morbum. A gondolat (a lélek indulatai vs. ratio) valószínüsíthetően Chrysipposig vezethető vissza. Szerinte, ha egy személy „természetes hajtóerejével” (a motiváció alapja, cselekvésre ösztönző erő) összhangban sétál, s a lábai által kifejtett mozgás nem túlzott, akkor bármikor meg tud állni, vagy meg tudja változtatni tempóját. Viszont ha valaki fut, ez már nem ilyen egyszerü. Szerinte a futáshoz hasonló dolog történik az emberi lélekben, ugyanis ha a „természetes hajtóerö” hirtelen megugrik, s több van belőle a kelleténél, akkor a léleknek meglepő és kiszámíthatatlan megnyilvánulásai lehetnek, s ebből következően az ember „furcsa” tetteket vihet véghez. Éppen emiatt ebből a hajtóerőből éppen annyira van szükség, amennyi biztosítja a józan ész és az érzelmek optimális működését. E chrysipposi modellben a személy tudatos döntése, mikor kezd futni, viszont ha már fut, nem tud megállni egy pillanat alatt. Lásd Gal. Plac. 4 ,2, 13-18.

${ }^{11}$ Sen. Ir. 2, 4, 1: „De hogy tudd, miképpen is kezdődnek a szenvedélyek, hogyan fokozódnak és törnek ki: az első felindulás nem szándékos, hanem mintegy előkészítése a szenvedélynek, illetve annak egyfajta fenyegetése; a másik fokozat az, amikor az aka-
} 
Seneca azt vizsgálja, hogy a harag ösztönösen vagy akaratlagosan, „,saját meggyőződésből” keletkezik-e bennünk. Szerinte az első „felindulás"(primus motus) nem szándékos, és egyfajta előkészítés a manifesztálódó szenvedélyre, a második fokozat, mikor az értelem nem tiltakozik, azaz a személy behódol a lelkében dúló érzelmeknek, és a harmadik fázisban pedig már teljesen lehetetlen a folyamatot visszafordítani, amikor a harag és az abból keletkező bosszú dominál az értelem felett, és mindenáron győzedelmeskedni akar.

Leírásában a lelket érő „,benyomásokat” nem lehet kivédeni, illetve az arra adott testi reakciókat visszafojtani, viszont a fegyelem, az akarat csökkentheti ezen hatások erejét, és a szenvedély teljes megnyilvánulását megakadályozhatja:

Primum illum animi ictum effugere ratione non possumus, sicut ne illa quidem quae diximus accidere corporibus, ne nos oscitatio aliena sollicitet, ne oculi ad intentationem subitam digitorum comprimantur: ista non potest ratio uincere, consuetudo fortasse et adsidua obseruatio extenuat. Alter ille motus, qui iudicio nascitur, iudicio tollitur. ${ }^{12}$

Ily módon a legfontosabb a fegyelem, az akarat, az önkontroll (obseruatio), amely által elérhetjük, hogy kiegyensúlyozott, az érzelmek negatív hatásától mentes életünk legyen. Az érzelmek hevesek és kiszámíthatatlanok, és ha nem szentelünk nekik elég figyelmet, betegséghez vezethetnek (morbus). A lélek betegségét a huruthoz hasonlítja, megjelenéskor még csak köhögést okoz, de ha nem figyelünk oda rá, állandóvá, krónikussá válhat, és tüdősorvadáshoz, súlyos kórsághoz vezet-

rat már nem tiltakozik, mintha meg kellene bosszulni, ha sérelem érte, és bünhődnie kellene annak, aki a jogtalanságot elkövette; a harmadik már kezelhetetlen indulat, amely nemcsak kötelességérzetből akar bosszút állni, hanem mindenáron, amely már az értelem fölébe kerekedett." Fordította: Kovács Mihály.

12 Sen. Ir. 2, 4, 2: "A lelket érő első benyomást nem tudjuk kivédeni az értelemmel, amint azt sem, amit a test reakcióiról mondtunk, tehát hogy mások ásítása ne késztessen minket is arra, hogy a hirtelen felébökött ujjak hatására ne csukódjanak be a szemeink: ezeket nem tudja az értelem legyőzni, bár a megszokás, illetve az állandó figyelem csökkentheti őket. Az a másik indulat, amely elhatározásból, szándékból keletkezik, ugyancsak elhatározással szüntethető meg." Fordította: Kovács Mihály. 
het. Seneca különbséget tesz a morbus és az adfectus között: a morbus maradandó jellemhiba, ${ }^{13}$ az adfectus viszont aktuális emocionális kirohanás. ${ }^{14} \mathrm{Az}$ adfectus gyakran jelentkezik és gyógyítható, de ha nem figyel rá az ember, komoly következményei lehetnek, azaz betegséggé fajulhat. A morbus ennél több, sőt minőségileg más: a hitvány ember folytonos téves vélekedése. Tehát a morbus a már megrögzült hibákat, a morális őrület jelenlétét jelöli, amelyek már beépültek a személyiségbe, míg az adfectus csak a kezdeti fázist, azaz az ictus animit. Az önkontroll által a minket érő benyomások, érzelmek hevességét csillapíthatjuk, azaz elkerülhetjük azok túlburjánzását, s a harmadik fázis visszafordíthatatlan állapotát.

Seneca szerint a sztoikus bölcset is érik elkerülhetetlen benyomások, érzelmek, ${ }^{15}$ de ő akaratával, rációjának erejével megakadályozza hatalmukat, és képes megtartani a lelki egészségét. Amíg az értelem a „gyeplőt" a kezében tartja, tud hatni az érzelmekre, és távol tud maradni tőlük, viszont ha megfertőződik általuk, akkor már nem tudja a hatalmában tartani azokat, pedig korábban még megfékezhette volna valamennyit. ${ }^{16}$ Ezt a jelenséget a mélybe zuhanó test analógiájával érzékelteti: ahogyan a zuhanó test sem tudja a földre érést lassítani vagy feltartóztatni, úgy a lélek sem tud „megálljt parancsolni” önmagának, ha a szenvedély egyszer a hatalmába kerítette, azaz magával rántja a mélybe. ${ }^{17} \mathrm{Az}$ akaratlan benyomásokat, érzelmi reakciókat meg kell különböztetni a tényleges szenvedélyektől, hiszen ezeket inkább eltüri a lélek, semmint teszi. A szenvedély tehát nem véletlenszerű felindulás, hanem a benyomások-

\footnotetext{
${ }^{13}$ Sen. Ep. 75, 11: morbi sunt inveterata vitia et dura (...) morbus est iudicium in pravo pertinax.

14 Sen. Ep. 75, 12: Adfectus sunt motus animi inprobabiles, subiti et concitati, qui frequentes neglectique fecere morbum.

15 Sen. Ir. 2, 2, 2: Ira praeceptis fugatur; est enim uoluntarium animi uitium, non ex his quae condicione quadam humanae sortis eueniunt ideoque etiam sapientissimis accidunt, inter quae et primus ille ictus animi ponendus est qui nos post opinionem iniuriae mouet.

${ }_{16}$ Sen. Ir. 1, 7, 3: Deinde ratio ipsa, cui freni traduntur, tam diu potens est quam diu diducta est ab adfectibus; si miscuit se illis et inquinauit, non potest continere quos summouere potuisset. Commota enim semel et excussa mens ei seruit quo inpellitur.

17 Sen. Ir. 1, 7, 4: rapiat illum oportet et ad imum agat pondus suum et uitiorum natura procliuis.
} 
nak való „behódolás”, amelyhez már az elme jóváhagyása kell: mert nem lehetséges bosszúról és büntetésről dönteni a lélek tudta nélkül. ${ }^{18}$

Seneca szerint a szenvedélyek, a harag és az abból fakadó bosszú kegyetlenséget szül, amely lelki betegség, s az őrültséggel azonos. Ilyen állapotban az embernek már gyönyörüséget jelent a kegyetlen tett: tunc illi dirus animi morbus ad insaniam pervenit ultimam, cum crudelitas versa est in voluptatem et iam occidere hominem iuvat. ${ }^{19} \mathrm{Ez}$ a jelenség általános, és felveti a kérdést: az emberölés és a gyilkosságok korlátozva vannak, de a háborúk és a nemzetek leigázása dicsőség? Kapzsiság és vérszomj uralkodik, a senatus és a népgyưlés szabadjára engedi a dühöt, és állami úton megparancsolják azt, amit magánúton tiltanak. ${ }^{20}$ Ezeknek az embereknek gyülölet, méreg és fegyver jár a nyomában, és éppen annyi veszedelem fenyegeti, mint amennyit ő okoz másoknak.

A harag és bosszú mellett Seneca több prózai müvében hangsúlyozza az abnormális félelem őrültségét is, bár bevallja, hogy az élet nehéz szituációi, sorscsapásai közepette nehéz „észnél maradni”:

Non est facile inter magna mala consipere. Itaque leuissima fere ingenia in tantum uenere formidinis ut sibi exciderent. Nemo quidem sine aliqua iactura sanitatis expauit, similisque est furentis quisquis timet: sed alios cito timor sibi reddit, alios uehementius perturbat et in dementiam transfert. Inde inter bella errauere lymphatici, nec usquam plura exempla uaticinantium inuenies quam ubi formido mentes religione mixta percussit. ${ }^{21}$

\footnotetext{
18 Sen. Ir. 2, 3, 4. Ira non moueri tantum debet sed excurrere; est enim impetus; numquam autem impetus sine adsensu mentis est, neque enim fieri potest ut de ultione et poena agatur animo nesciente. Kontextus: Seneca (hasonlóan Epiktétoshoz) megkülönbözteti az akaratlan érzelmi reakciókat a tényleges, valódi szenvedélyektől, amelyek az előbbiekből törnek felszínre az értelem jóváhagyásával. Lásd továbbá Sen. Ir. 3, 16, 7; LONG (2015: 775).

${ }^{19}$ Sen. Clem. 25, 2: „Gyönyörködik az emberek kínjaiban; s ez a szörnyű lelki betegség az őrültség határáig jut, amikor a kegyetlenség már gyönyörűséget jelent neki, és öröm számára az emberölés." Fordította: Szőke Ágnes.

20 Sen. Ep. 95, 30.

${ }^{21}$ Sen. Q. N. 6, 29, 2-3: „Nagy bajok közepette nem könnyű észnél lenni. Így a legbefolyásolhatóbb jellemeket bizonyára annyira hatalmába kerítette a rettegés, hogy öntudatukat vesztették. Senki nem ijed meg úgy, hogy elméje épsége meg ne szenvedné va-
} 
Aki befolyásolható, akinek önkontrollja nem elég fejlett, hatalmába kerítheti a rettegés, az abnormális félelem olyan mértékben, hogy tudatát vesztheti. Seneca szerint senki sem ijed meg úgy, hogy valamilyen szinten elméje épsége meg ne szenvedné, ily módon, aki fél, hasonló az őrülthöz. Ugyanakkor minden embert másként érint a félelem, van, aki hamar kigyógyul belőle, viszont van, akit ténylegesen tébolyba (dementia) sodor. A háború szörnyűségének pszichológiai következményeit is felhozza: nem véletlen, hogy ilyenkor találkozunk a legtöbb tébolyult elmével, akik össze-vissza bolyonganak céltalanul, és az önkívületi jóslásban hisznek, amit egyfajta vallásos képzetekkel keveredő rettegés jellemez.

\section{Insania publica \& insania quae medicis traditur}

A sztoikusok különbséget tettek az őrület két fajtája, az orvosi és az etikai, azaz az emberiség általános őrülete között. Az emberiség e „közös őrülete" az erény és a bün sztoikus felfogásáshoz vezethető vissza. Nem tudjuk, hogy az általános őrültség fogalma honnan származik, Ahonen szerint Chrysippos az első sztoikus, aki használja, de lehetséges, hogy az elmélet cinikus eredetű.. ${ }^{22}$ Caelius Aurelianus orvosi szakíró írásában a sztoikusok szerint az egyik őrület a bölcsesség hiányából fakad (insipientia), a másik (alienatio mentis) pedig az értelem hiányában és testi tünetekben nyilvánul meg. ${ }^{23}$ Cicero az orvosi értelemben vett kognitív zavart furornak, az etikai értelemben vett őrületet pedig insaniának nevezi. ${ }^{24} \mathrm{~A}$ latin insania terminus Cicero meglátásában az insipientia jelenségét, ily módon az erkölcsi tökéletlenség mentális állapotát jelöli. ${ }^{25}$

Seneca a sztoikus elődöket követve megkülönbözteti a kétfajta insaniát, azaz hogy a „szokásos” őrület és az orvosok által kezelt mentá-

\footnotetext{
lamennyire, és mindenki, aki fél, hasonló az őrülthöz - de van, akit hamar magához enged térni a félelem, van, akit hevesebben felzaklat és tébolyba sodor. Ezért van, hogy háborúk idején elborult elmével bolyonganak az emberek, és sehol nem találod több példáját az önkívületi jóslásnak, mint ahol a lelkeket vallásos képzetekkel keveredő rettegés rázza meg." Fordította: Kopeczky Rita.

22 Bővebben lásd AHONEN (2014: 103).

${ }^{23}$ Cael. Aur. Tard. 1, 144.

${ }^{24}$ Cic. Tusc. 3, 11.

${ }^{25}$ Cic. TD 3, 8-10.
} 
lis betegség (insaniam publicam et hanc quae medicis traditur) ${ }^{26}$ között nincs egyéb különbség, mint hogy az előbbiek testi betegséggel küzdenek, amazok pedig a téves meggyőződésekkel, azaz szellemi betegséggel (morbo laborat, illa opinionibus falsis). ${ }^{27}$ A De beneficiisben a kétfajta insania szociális életben való megkülönböztetéséről ír, ti. hogy bár „mindenkit őrültnek tartanak, mégsem orvosolják valamennyit hunyorral", ${ }^{28}$ tehát elkülöníti az orvosi és a filozófiai hatáskörbe tartozó őrületet, ugyanakkor hasonlóságot is vél felfedezni. Szerinte az egyik testi eredetü (ex valitudine), a másik a lélek egészségének hiányából ered (animi mala valitudo), azonban tüneteikben nagyon is hasonlóak. A testi eredetü lelki zavar esetén a fekete epét ${ }^{29}$ kell kezelni és az örület okát eltüntetni. Ugyanez a teendő a lelki őrületben is, el kell távolítani a téves attitüdöket, meggyőződéseket, hiedelmeket. Seneca a lelki eredetü insaniát morbusként jelöli meg, amely a rögzült hibákban manifesztálódik, mint például a kapzsiság és a nagyravágyás, amelyek állandó személyiségjellemzővé, tulajdonsággá válnak. ${ }^{30} \mathrm{Az}$ „általános” őrületet máshol a communis insania terminusokkal jelöli, amikor a lélek természettel való összhangjáról beszél. Seneca szerint a lélek kiegyensúlyozott állapotát, a természettel való összhangot az emberek „általános” örülete akadályozza meg. ${ }^{31}$ Zénónt idézi, aki az emberi lélek kiteljesedését a természet törvényeivel összhangban való együttélésben fogalmazta meg. Ez az erényes életet jelenti, amely egyaránt jelenti az univerzum természetével való együttélést, és minden ember sajátos természetével való együttélés összhangját. Ugyanakkor az ember hajlama a különböző érzelmekre veleszületett jelenség, és bár a sztoikus filozófiával lehet fejleszteni az ember személyiségét, az érzelmekre való hajlam megmarad. Ha egy

\footnotetext{
${ }^{26}$ Sen. Ep. 94, 17.

27 Uo.

28 Sen. Ben. 2, 35, 2: insanire omnes dicimus, nec omnes curamus elleboro. A hunyor tipikusan a testi eredetü elmebetegség gyógyításához használatos, és az orvosi relevancia hatáskörébe tartozik. Ehhez ld. bővebben: MAIERON (2018: 5-18).

${ }^{29}$ Utalás a hunyorra.

${ }^{30}$ Sen. Ep. 75, 11-12: morbi sunt inveterata vitia et dura, ut avaritia, ut ambitio; nimio artius haec animum inplicuerunt et perpetua eius mala esse coeperunt.

${ }^{31}$ Sen. Ep. 41, 9: sed hanc difficilem facit communis insania: in vitia alter alterum trudimus. Ld. D.L. $87-88$.
} 
ember teljes mértékben az erényes élet útján jár is, és minden addigi „hibájától” megszabadult, akkor sem képes a különböző szenvedélyekre való veleszületett hajlamát levetkőzni. ${ }^{32}$ Ugyan a ratio követése segít az erényes élet elérésében, mégsem tud győzedelmeskedni az emberi természeten. ${ }^{33}$ Ily módon az insania publica jelenségét elkerülhetetlennek és veleszületettnek gondolja, s a sztoikus bölcs személyiségének kiteljesedett volta mintegy elérhetetlen állapotnak tünik fel. Ugyanakkor Seneca szerint minden embernek megvan a képessége a bölcsesség elérésére, bár valóban nagyon kevesen érik el ezt a célt. A sztoikus bölcs ember nem mítosz: bár rendkívül ritka, valóban megjelent a földön, és újra és újra meg fog jelenni. ${ }^{34}$ Üzenetének célja a sapientiae studium, a bölcsesség felé való igyekvés, amely az élet valódi értelme. A bölcsesség eléréséhez pedig a filozófia megismerésére van szükség, amely olyan, mint egy bevehetetlen fal: bár a sors ostromgépekkel akar rajta áthatolni, nem tud. ${ }^{35}$

\section{Seneca filozófiai terápiája}

A hellenisztikus időszakban a filozófia gyógyító, terápiás jellegü aspektusa $^{36}$ - amely egyáltalán nem volt újdonság a görög gondolkodásban egyre inkább szerepet töltött be az filozófiai irodalomban, és ez a tendencia kedvező fogadtatásra talált Rómában, Seneca munkáiban is. Guillemin "Sénèque directeur d'âmes" ${ }^{37}$ kifejezése híven visszaadja a filozófus filozófiai üzenetének lényegét: írásainak célja az emberek morális szempontból való fejlesztése a boldogság elérése érdekében (vita beata). Seneca azt állítja, hogy a filozófusnak kötelessége segíteni a már

\footnotetext{
32 Sen. Ep. 57, 4: naturalis affectio inexpugnabilis rationi.

${ }^{33}$ Sen. Ep. 11, 1: Nulla enim sapientia naturalia corporis aut animi vitia ponuntur: quidquid infixum et ingenitum est lenitur arte, non vincitur.

${ }^{34}$ Sen. Const. Sap. 7, 1: Non fingimus istud humani ingenii uanum decus nec ingentem imaginem falsae rei concipimus, sed qualem conformamus exhibuimus, exhibebimus, raro forsitan magnisque aetatium interuallis unum. Vö.: 2, 1 .

35 Sen. Ep. 82.

36 SETAIOLI (2014: 239).

37 SETAioli (2013: 200).
} 
látszólag reménytelen helyzetben lévő embereken is; ${ }^{38}$ de általában üzenetével olyan embereket céloz meg, akik, mint ő, az erény és a bölcsesség felé próbálnak lépni (vö. Panaitios terminusával a prokoptontes, illetve, ahogy ő mondja, a proficientes). ${ }^{39}$ Ugyanakkor gondolkodásmódja igen pozitívnak mondható, hiszen szerinte akkor sem kell kétségbe esni, ha már az etikai értelemben vett örület „megkeményedett” a lélekben, mert a remény mindig ott van velünk (Sed nec indurata despero). ${ }^{40}$

Seneca retorikai-poétikai eszközökkel ábrázolt terápiájának bölcs utasításai (praecepta), meditációs technikái és példázatai (exempla) révén az olvasót valódi belső dialógusra késztethetik, amelynek remélt hatása a befogadó személyiségének megváltozása. ${ }^{41}$ Ugyanakkor jogosan merülhet fel a kérdés, hogy az írott szövegek milyen mértékben alkalmazhatóak sikeresen terápiás eszközként. Erre a kérdésfelvetésre felhozhatjuk példaként Sókratést, akinek fő ellenvetése az írással szemben az volt, hogy annak statikus természete miatt az élő interakció nem valósulhat meg, és ily módon valódi dialektikát nem közvetít. ${ }^{22}$ Seneca ennek a hiányosságnak láthatóan tudatában van, és több esetben megjegyzi az írott terápia hátrányait. ${ }^{43}$ Ugyanakkor Lucilius szicíliai távolléte, illetve Seneca célja, hogy az utókort terápiás tanácsokkal lássa el, indokolttá teszi a formaválasztást:

Illis aliqua quae possint prodesse conscribo; salutares admonitiones, velut medicamentorum utilium compositiones, litteris mando, esse illas efficaces in meis ulceribus expertus, quae etiam si persanata non sunt, serpere desierunt. ${ }^{44}$

\footnotetext{
${ }^{38}$ Sen. Ep. 29, 3: certum petat, eligat profecturos, ab iis quos desperavit recedat, non tamen cito relinquat et in ipsa desperatione extrema remedia temptet.

${ }^{39}$ Lásd bővebben LONG-SEDLEY (2015).

40 Sen. Ep. 50, 6.

${ }^{41}$ Ld. bővebben NÉMETH (2019: 45).

${ }^{42} \mathrm{Az}$ írott szövegekkel kapcsolatos kritika Platónnál is megjelenik (Pl. Phdr. 275b277e).

${ }^{43}$ Pl. Sen. Ep. 6, 45, 84, 88, 89, 108.

${ }^{44}$ Sen. Ep. 8, 2: „Az utókor ügyével foglalkozom. Nekik írok össze néhány dolgot, amelyek hasznukra lehetnek. Mint bevált gyógyszerek receptjeit, üdvös figyelmeztetéseket foglalok írásba, miután hatásos voltukat a saját sebeimen megállapítottam. Az én sebe-
} 
Seneca megosztja tapasztalatait olvasóközönségével, és reméli, hogy ezáltal egy lelkileg egészségesebb utókor veszi kezdetét. Az emberi téves meggyőződéseket, „,sebeket”- amint a fenti idézetben is láthatjuk gyakran a ragályhoz, a járványhoz hasonlítja: nulla pestis humano generi pluris stetit, ${ }^{45}$ amely nem csupán egyes embereket sújt, hanem olykor embertömegeket. Éppen ezért ébernek kell lenni, és szembe kell szállni a nagy méretet öltött insaniával.

Seneca szerint azért gyógyulunk nehezen, mert valójában nem tudjuk, hogy betegek vagyunk, ha a kezelést el is kezdjük, sok időbe telik az insania publica erejét megtörni. ${ }^{46}$ Ráadásul megnehezíti a lelki betegség felismerését és gyógyítását az a tényező, hogy minél súlyosabb a baj, annál kevésbé érzik az emberek (quo quis peius se habet, minus sentit). ${ }^{47} \mathrm{Az}$ önreflexió és önkontroll jelentőségét propagálja, hiszen az insania kezdeti stádiumában lévő betegség felismerése nagy eséllyel vezethet gyógyuláshoz, ${ }^{48}$ viszont mikor már a rossz szokások a személyiség részét képezik, sokkal nehezebben a helyzet. Éppen emiatt a De irában felmutatott terápiája a következő lépésekből áll: az első, hogy ne haragudjunk meg, a második, hogy letegyünk róla, ha esetleg megharagudtunk, a harmadik pedig, hogy a többi ember haragját is orvosoljuk. ${ }^{49}$

Az első lépést prevenciós eljárásnak is nevezhetjük, Seneca szerint időről időre fel kell mutatnunk magunk előtt a harag rossz tulajdonsá-

im, ha nem is gyógyultak meg véglegesen, nem terjednek tovább." Fordította: Bollók János. Vö. 22, 2; 79, 17. Seneca levelei a mindenkori olvasóhoz is szólnak, és úgy érezzük, hogy fiktív beszélgetésbe kerülünk a filozófussal. Ezt a fiktív élményt az olvasás lehetősége teremti meg: Sen. Ep. 67, 2: Si quando intervenerunt epistulae tuae, tecum esse mihi videor et sic adficior animo, tamquam tibi non rescribam, sed respondeam, Itaque et de hoc, quod quaeris, quasi conloquar tecum, quale sit, una scrutabimur.

45 Sen. Ir. 1, 2, 1.

46 Sen. Ep. 50, 4-6.

47 Sen. Ep. 53, 7.

48 Sen. Ir. 3, 10, 1: Optimum est itaque ad primum mali sensum mederi sibi.

${ }^{49}$ Sen. Ir. 3, 5, 2: Sed cum primum sit non irasci, secundum desinere, tertium alienae quoque irae mederi, dicam primum quemadmodum in iram non incidamus, deinde quemadmodum nos ab illa liberemus, nouissime quemadmodum irascentem retineamus placemusque et ad sanitatem reducamus. 
gait és vádlóként lépni fel ellene. ${ }^{50}$ Tartsuk szem előtt, hogy a szenvedélyek közül a harag követkeményei a legsúlyosabbak: gyülölet, háború, halál, gyász jár a nyomában. ${ }^{51}$ További prevenciós technikaként említi a nyugodt, békés emberek közelségét, hiszen az egymás közelségében lévők átveszik egymás jellemét. ${ }^{52}$

Második lépésként a haragra hajlamos embereknek azt tanácsolja, hogy foglalkozzanak tudományokkal és müvészetekkel, hiszen Pythagoras is az indulatait a lant hangjával csendesítette le. ${ }^{53}$ Seneca szerint bizonyos dallamok nyugtatóan hatnak az emberre, és a lélek feszültségét feloldják. Emellett az olvasás fontosságát is kiemeli, amely a lélek "spirituális táplálékaként" funkcionál, ugyanakkor inti olvasóját, hogy csak a legkiválóbb szerzőket forgassa, és olvassa őket újra és újra, hogy a helyes gondolatok "gyökeret eresszenek" lelkében. ${ }^{54}$ Kerülni kell továbbá a jogi pereket, a fórumot, a politikát, valamint a test kifárasztását, hiszen a fáradtság elősegíti a harag kialakulását. ${ }^{55}$ Ugyanezen okok miatt a haragra hajlamos emberek igyekezzenek kerülni az éhséget és a szomjúságot is, hiszen ezek „fellobbantják a lelket." ${ }^{66}$ Fontos kiismerni magunkat, hogy mik azok a tényezők, amelyek felbosszantanak minket, majd próbáljuk meg ezeket elkerülni; ne legyünk kíváncsiak, próbáljunk szemet hunyni a sértések felett, hiszen nem az a lényeg, hogyan történt egy sértés, hanem hogyan türik. ${ }^{57}$ Harcra hívja olvasóit a harag ellen: pugna tecum ipse..$^{58}$ Seneca szerint, ha valóban háborút vívunk ellene, nem győzhet le minket. Árulkodó jeleit ássuk el lelkünk mélyére, hogy rejtve maradjon és titokban.

\footnotetext{
50 Sen. Ir. 3, 5, 3: Accusanda est apud nos, damnanda; perscrutanda eius mala et in medium protrahenda sunt; ut qualis sit appareat, comparanda cum pessimis est.

51 Sen. Ir. 3, 7.

${ }^{52}$ Sen. Ir. 3, 8, 1: sumuntur a conuersantibus mores et ut quaedam in contactos corporis uitia transiliunt, ita animus mala sua proximis tradit.

53 Sen. Ir. 3, 9, 2.

${ }^{54}$ Sen. Ep. 2, 2,. Lásd továbbá 45, 1; 88, 36-40; 89, 18; Tranq. 9, 4-6.

55 Uo. 3, 9, 3: aeque cauere lassitudinem corporis; consumit enim quidquid in nobis mite placidumque est et acria concitat.

56 Uo. 3, 9, 4: exasperat et incendit animos.

${ }^{57}$ Sen. Ir. 3, 11, 3.

58 Sen. Ir. 3, 13, 1.
} 
A terápiás gyakorlat fontos eleme továbbá egy erkölcsi ideál elképzelése, akit mint exemplumot „helyezünk” lelkünkbe, és hozzá mérten reflektálunk magunkra a meditáció során. ${ }^{59}$ Seneca szerint, amikor a tanítvány már nagyon előrehaladott, elbocsáthatjuk az ideált, és végül önmagunk barátaiként, egyfajta alteregóként folytathatjuk tovább a meditációt teljes összhangban önmagunkkal. ${ }^{60}$ Seneca filozófiája szerint az isteni ösztön, a ratio in anima perfecta ${ }^{61}$ mindenkiben megtalálható, amely természeténél fogva tölt el minket pozitív gondolatokkal. Ahhoz viszont, hogy ezt a fejlődési szintet elérjük, egy képzelt ideálhoz mérten folyamatos belső, önmagunkra reflektáló dialógust kell folytatnunk magunkkal.

Harmadik lépésként - ha „összerendeztük” lelkünket - meg kell tanulni mások haragját, őrületét gyógyítani, hiszen nem elég csupán egészségesnek lenni, gyógyítani is kell. ${ }^{62}$ A módszert mindig az ember jelleme szerint kell megválasztani, hiszen némelyeket már a kérés is meggyőzi, másokat megfélemlítéssel, dorgálással lehet megfékezni, vannak, akiket a szégyenérzet téríti el tervüktől, végül pedig a beavatkozás halogatását ajánlja, de ehhez Seneca szerint csak legvégül folyamodjunk. ${ }^{63}$ A személyre szabott terápiát szorgalmazza, szerinte nem lehet ugyanazt a gyógymódot alkalmazni a különféle betegségben szenvedők esetében (pro cuiusque morbo medicina quaeratur). ${ }^{64}$ Szerinte ahány féle lélek, annyi féle mentális baj létezik, s mindegyik esetben meg kell találni a megfelelő gyógymódot. ${ }^{65}$

\footnotetext{
59 Sen. Ep. 11, 9: Aliquem habeat animus quem vereatur, cuius auctoritate etiam secretum suum sanctius faciat.

${ }^{60}$ Sen. Ep. 94, 2, 31, 50-51.

61 Sen. Ep. 41, 8.

62 Sen. Ir. 3, 39, 1: Videamus quomodo alienam iram leniamus; nec enim sani esse tantum uolumus, sed sanare. A középső sztoa megalapítója, Panaitios gondolkodása középpontjába a gyakorlatiasságot és a közösséget helyezi, felismeri, hogy a társadalomban alapvetőek a személyközi viszonyok, amelyek az állam alapját jelentik. Emberideálja nem a bölcs, hanem a bölcsességben folyvást előrehaladó ember (prokoptón), aki törekszik az erényre, és a közösség javáért is cselekszik. Seneca esetében ez a „közösségi színezet” egyértelműen megmutatkozik. LONG-SEDLEY (2015: 786).

${ }^{63}$ Sen. Ir. 3, 1, 2.

64 Sen. Ir. 1, 16, 4.

65 Uo.
} 
A terápiás eljárás első szakasza gyakran agresszív hangvételü, hiszen az őrült szenvedély hálójába került emberre gyöngéden, „,szép szavakkal" nehezen lehet hatni. ${ }^{66}$ Először az érzelmekre kell hatni, és utána az értelemre (admonitio). ${ }^{67}$ Nem szabad a dühkitörést rögtön rábeszéléssel kezelni, mert a harag ilyenkor süket és őrjöngő (surda est et amens). ${ }^{68}$ Az első lendület túl heves, csak miután lecsillapodott, lehet tőle várni, hogy „mérlegeljen”. A legfontosabb a haragvó ember megnyugtatása az érzelmeire hatva, amelyhez több terápiás eszközt is biztosít: ha hevesebb a düh, akkor olyan dolgokat kell neki felmutatni, aminek nem tud ellenállni, vagy szégyenérzetet, illetve félelmet vált ki belőle; ha gyengébb, akkor beszélgetést kell kezdeményezi vele a számára kedves vagy újnak számító témákról, s ily módon a kíváncsiság eltereli a figyelmét őrületéről. ${ }^{69}$ Tehát a haragvó ember érzelmeire való hatás csak az első lépés a ratio helyreállítása felé. ${ }^{70}$

Seneca szerint a közvetlen kapcsolat meglétének jelentősége elengedhetetlen az egészséges mentális állapot visszaállítása és fenntartása érdekében. Ez a kötelék egyfajta tükörként vagy alteregóként értelmezhető, miáltal az egyén jobban megismerheti önmagát. ${ }^{71} \mathrm{~A}$ De tranquillitate animiben Serenus ki is mondja, hogy Seneca olyan a számára, mintha az orvosa lenne. ${ }^{72}$ Nyilvánvalóan itt az orvos kifejezést a lélek orvosaként kell értelmezni, aki terápiás útmutatásaival kigyógyítja Serenust betegségéből. A biztatás, az önmegerősítés, a reménykeltés terápiás technikája igen fontos szerepet tölt be, azaz annak kommunikálása, hogy Serenus helyes úton jár, csak bízzon magában.

Fontos továbbá megemlíteni Seneca halállal kapcsolatos filozófiai terápiáját, ${ }^{73}$ amelyet főként a Vigasztalásokban és az Erkölcsi levelekben fejt

\footnotetext{
${ }^{66}$ Lásd pl. Sen. Ep. 75, 7.

67 Pl. Sen. Ep. 60,1: queror, litigo, irascor ; vö. Ep. 25, 1; 51, 13.

68 Sen. Ir. 3, 39.

${ }^{69}$ Sen. 3, 39, 4: Omni arte requiem furori dabit: si uehementior erit, aut pudorem illi cui non resistat incutiet aut metum; si infirmior, sermones inferet uel gratos uel nouos et cupiditate cognoscendi auocabit.

70 Vö. SETAIOLI (2000: 141-15)

${ }^{71}$ Sen. Ep. 27, 1: Továbbá lásd LONG (2009: 4).

72 Sen. Tranq. 1, 2.

${ }^{73}$ Sen. Ep. 70, 18: nullius rei [sc. quam mortis] meditatio tam necessaria est.
} 
ki, de egyéb írásaiban is találhatunk fontos megállapításokat ezzel kapcsolatban. Ezekben a levelekben elsősorban a gyász fájdalmát, a halállal való szembesülés elhárításának jelenségét vizsgálja, amely érzéseket természetellenesnek lát. Kérdésként veti fel: az emberek miért képtelenek megbirkózni szeretteik elvesztésével? El kell fogadnunk a halál természetes voltát, amely közös végzetünk. ${ }^{74}$ Marciának a delphoi jóshely intelmét említi meg: „Ismerd meg önmagad”, amely azt jelenti, hogy elfogadjuk az ember törékenységét. ${ }^{75}$ Aki beismerte a halál természetességét, a szerettei elmúlását is filozófushoz méltón viseli. ${ }^{76}$ Ugyanakkor a mértéktartó gyászt nem utasítja el, hiszen természetes, hogy szeretteink elvesztésekor fájdalmat érzünk, viszont a túlzásba vitt gyász már egyáltalán nem az. ${ }^{77}$

Mivel a halál bármikor és bármi/bárki által elérkezhet hozzánk, lelkileg fontos a halálra való felkészülés. ${ }^{78} \mathrm{~A}$ halálra való felkészülés voltaképpen a meditációs gyakorlatok egyike, amely révén minden napunkat úgy tekintjük, mintha az utolsó volna, és jelenünk minél értelmesebb megélésére törekszünk. Luciliusnak írja: omnes horas complectere. ${ }^{79} \mathrm{Ha}$ erényesen élünk a természettel és a sztoikus filozófiával összhangban, nem számít, hogy mikor érkezik el életünkbe a halál, hiszen csak annak tünik rövidnek az élet, aki elvesztegeti azt. Elismeri, hogy a halál rossznak látszik, a létfenntartás ösztöne, az ismeretlentől való félelem, illetve az alvilágról szóló történetek félelemkeltése miatt. Tehát valójában a közhiedelem miatt félünk a haláltól, amelyek csupán szavak, hiszen senki sem tud tapasztalatból mesélni róla. ${ }^{80}$ Seneca szerint nem kell félnünk a fájdalomtól sem, amely a halált kíséri, hiszen vagy kibírható

\footnotetext{
${ }^{74}$ Sen. Cons. Polyb. 1, 3.

75 Sen. Cons. Marc. 11, 2-3.

${ }^{76}$ Sen. Ep. 99, 6-8.

77 A gyász mértékletességéről lásd még: Ep. 63.

${ }^{78}$ Sen. Ep. 4, 7-9. Ez az ún. praemeditatio futurorum malorum tipikus sztoikus technikája: vö: ARMISEN-MARCHETTI (2008: 61). Epiktétosnál és Marcus Aureliusnál is találkozhatunk ezzel a toposszal: a halál megtanulásával és a vele való szembenézéssel. Vö. HADOT (2010: 133, 159).

${ }^{79}$ Sen. Ep. 1, 2.

${ }^{80}$ Sen. Ep. 91, 19-21.
} 
vagy rövid ideig tart. ${ }^{81}$ Hangsúlyozza, hogy a halálfélelmen való győzedelmeskedés hozzájárul más félelmeink legyőzéséhez is, tehát segít felülkerekedni a jövő problémáitól való rettegésen. ${ }^{82}$ Természetesen mindezeket folyamatosan tudatosítanunk kell magunkban, és lelkigyakorlatok révén interiorizálni.

Összefoglalva Seneca filozófiai terápiáját, megállapíthatjuk, hogy Seneca a sztoikus filozófiát a lélek „gyógyszereként” (remedium) 83 ajánlja és alkalmazza, amely elengedhetetlen a lelki nyugalom eléréséhez. Terápiája több lelkigyakorlatot tartalmaz, mint az admonitio (amely föként az érzelmekre hat, és gyakran agresszívabb hangvételű), a meditatio (önvizsgálat, választott ideálok emlékezetbe vésése, a halálra való előzetes felkészülés), az intellektuális technikák alkalmazása (olvasás, kutatás, művészetek, zenehallgatás). A filozófia révén az önkontroll, a racionális gondolkodás dominanciája megszilárdul, és ily módon nem kell félni attól, hogy a szenvedélyek átveszik az irányítást, és az insania felüti a fejét. Nem tagadja, hogy könnyü ezen hibákba esni, viszont terápiás eszközeivel kiutat mutat az insania publica jelenségéből. ${ }^{84}$ Erőteljesen hangsúlyozza: az életet nem szabad haszontalan tevékenységekkel elrontani, el kell köteleznünk magunkat teljes mértékben az önfejlesztés mellett. A studium sapientiae nélkül az élet kiszámíthatatlan labirintus. ${ }^{85}$ Csak a filozófiában lehet megtalálni az útmutatást, az északi sarkcsillagot, ${ }^{86}$ amely biztonságosan a cél felé vezet, és amely által lelki egészségünket fenntarthatjuk. Seneca számára a bölcsesség müvészet: ${ }^{87}$ valójá-

\footnotetext{
${ }^{11}$ Sen. Ep. 24, 1-17. Lásd továbbá Sen. Ep. 30, 14; illetve BARCSI (2015: 61-131).

${ }^{2} \mathrm{Pl}$. Sen. Ep. 24. Ebben a levélben Seneca próbálja megnyugtatni Luciliust, aki egy törvényszéki vizsgálat kimenetele miatt aggódik. A filozófus hangsúlyozza a lelki felkészülés fontosságát: reméljük a legpozitívabb döntést, de fel kell készülnünk a legrosszabbra. Mindennek a kulcsa a halál elfogadása és tudomásul vétele.

83 Sen. Tranq. 2, 4: sumes tu ex publico remedio quantum voles.

${ }^{84}$ Robertson és Codd az antik terápia modern kognitív pszichoterápiával való összehasonlítására tett kísérletet. Az összehasonlítás releváns pontja az, hogy a beteget felelős ügynökként kezelik, aki képes megérteni jelenlegi szorongásának, dühkitöréseinek etc. okait, és enyhíteni szándékos terápiás cselekvési program vagy gondolatok révén. Bővebben lásd ROBERTSON-CODD (2019).

85 Sen. Ep. 44, 7.

86 Sen. Ep. 71, 2-4.

${ }^{87}$ Sen. Ep. 29, 3: sapientia ars est; 90, 44: ars est bonum fieri.
} 
ban az egyetlen valódi művészet, amely olyan elveken nyugszik, amelyek megtanulhatók. Bizonyára csak nagyon kevesen lesznek képesek megtanulni ezt; csak a sapiens az igazi "élet múvésze", az artifex vitae. ${ }^{88}$ Ennek ellenére egész életünkben törekednünk kell ennek az ideális célnak az elérésre.

\section{Felhasznált irodalom}

AHOnen 2014 M. Ahonen, Mental Disorders in Ancient Philosophy (Studies in the History of Philosophy of Mind 13), Helsinki, 2014.

ARMISEN-MARCHETTI 2008

M. ARMISEN-MARCHETTI, Imagination and Meditation in Seneca: The Example of Praemeditatio, in: J. G. Fitch (ed.), Seneca, Oxford, 2008, 102-113.

BARCSI 2015

BARCSI T., Mit jelent megtanulni meghalni? I. Seneca és Montaigne halálfelfogásáról, Nagyerdei Almanach, 1 (2015), 61-131.

GILL 2013

C. GILL, Philosophical Therapy as Preventive Psychological Medicine, in: W. V. Harris (ed.), Mental disorders in the Classical World, Leiden-Boston, 2013, 339-362.

HADOT 2010

P. HADOT, A lélek iskolája. Lelkigyakorlatok és ókori filozófia, Budapest, 2010.

LONG 2009

A. A. LONG, Seneca and the self: why now? in: S. Bartsch - D. Wray (eds.), Seneca and the self, Cambridge, 2009.

LONG-SEDLEY 2015 A. LONG - D. N. SEDLEY, A hellenisztikus filozófusok, Budapest, 2015.

MAIERON 2018 M. A. MAIERON, On the hellebore trail an anthropological research into madness, Medicina Historica, 2 (2018) 5-18.

ROBERTSON-CODD 2019

D. ROBERTSON-T. CODD, Stoic Philosophy as a Cognitive-Behavioral Therapy, The Behavior Therapist, 42 (2019), 42-50.

SETAIOLI 2013

A. SETAIOLI, La philosophie comme thérapie, transformation de soi et style de vie chez Sénèque, Vita Latina, 187-188 (2013), 200-221.

SETAIOLI 2014

A. SETAIOLI, Philosophy as Therapy, Self-Transformation, and "Lebensform", in: A. Heil - G. Damschen (eds.), Brill's Companion to Seneca: Philosopher and Dramatist, Leiden-Boston, 2014, 239256.

SteIger 1983 K. SteIger, Sztoikus etikai antológia, Budapest, 1983.

88 Sen. Vit. Beat. 8,3; Ep. 90, 27; 95, 7. 


\section{The phenomenon and therapy of insania of philosophical com- petence in Seneca's prose}

In my study, I examine Seneca's views about insania, in terms of its various causes, manifestations, and treatments, since he has a deep interest in the various psychological states of humans. As a Stoic philosopher, he thinks of insania publica as the prevailing phenomenon in the world, and mostly depicts it in passions, especially in anger and the ensuing revenge. In his description, the sage is characterized by personal responsibility, self-control, freedom from passions, and insania occurs when emotions prevail over rational thinking. Rationality must triumph over the irrational forces in the soul, and in his prose works he offers therapy and life-management strategy for the disease of the soul caused by passions.

Keywords: Seneca, insania, therapy, passion, Stoic philosophy 